\title{
Determination of Emergency Spare Parts using the Logistics and Maintenance Perspective on Power Plants
}

\author{
Ennol Endrianto ${ }^{1 *}$, Farizal $^{2}$ \\ ${ }^{1}$ Faculty of Engineering, Universityof Indonesia,Depok, Indonesia \\ ${ }^{2}$ Faculty of Engineering, University of Indonesia, Depok, Indonesia \\ ennol109@gmail.com
}

\begin{abstract}
The purpose of this study is to determine the type and number of spare for plant operation and maintenance planning. The method used in this study is a multi-criteria classification with a logistic perspective as well as maintenance. This study uses recommendation data from the manufacturer as an initial solution totaling 110 items per one power plant location from five locations to be calculated and grouping according to VED needs (Vital, Essential, Desireable). After knowing what spare parts must be provided, we will look for the number of spare parts by using expert judgment as a determinant of emergency spare parts. The results of the research have shown that the type and number of spare parts are more efficient compared to the manufacturer's recommendations. The reduction in the number of spare parts that must be stocked as a whole drops to only $71 \%$ and costs also decrease in the initial planning offered by the manufacturer to $72 \%$. In total, the use of the above method can reduce inventory costs by $28 \%$ from the initial tender plan where the amount can be used as a bargaining reserve value in the overall O\&M price to the owner.Productivity at the power plant is the most important performance in the operation and maintenance industry, productivity is much influenced by the availability of spare parts in the framework of maintenance of machinery, so that the minimum stock of emergency spare parts that must be calculated at the beginning of the tender must be truly calculated in order to avoid operation failure due to absence of spare parts. This paper tries to fill the gap in the literature regarding criteria from a logistic and maintenance point of view that is suitable for power plants where there is very little research in this area. Determination of the number of spare parts is an added value that is trying to display in this paper.
\end{abstract}

Key words: minimum stock, emergency spare parts, multi criteria classification, VED

\section{INTRODUCTION SECTION}

At present, Indonesia's electrification ratio in 2019 has exceeded the target of the plan, the Minister of Energy and Mineral Resources revealed that the electrification ratio currently reaching $98.1 \%$ has exceeded the target Rencana Pembangunan JangkaMenengahNasional (RPJMN) in 2019 amounting to $97.5 \%$. However, there are still around $2 \%$ or more than 5 million people who have not enjoyed the lighting. The challenge to get to the electrification ratio of $99.9 \%$ is also not easy, it requires seriousness to reach the target, considering the area that must be electrified is in a remote and difficult to reach area. The power plant construction is carried out in accordance with the RUPTL, which is compiled annually. The Ministry of Energy and Mineral Resources in 2019 compiled 2019-2028 RUPTL which also became a guideline in the 35,000 MW electricity program. This RUPTL continues to be reviewed from various aspects, for example the rate of economic growth, electricity demand and others. The Ministry of Energy and Mineral Resources detailed that in 2020 the program progress will increase to $9,422 \mathrm{MW}$. Next in 2021 it is projected to increase by $5,060 \mathrm{MW}$ and in 2022 by 4,033 MW. In 2023 it is projected that there will be an increase in progress of 3,907 MW, then in 2024 3,592 MW and in 2025 1,275 MW [1].

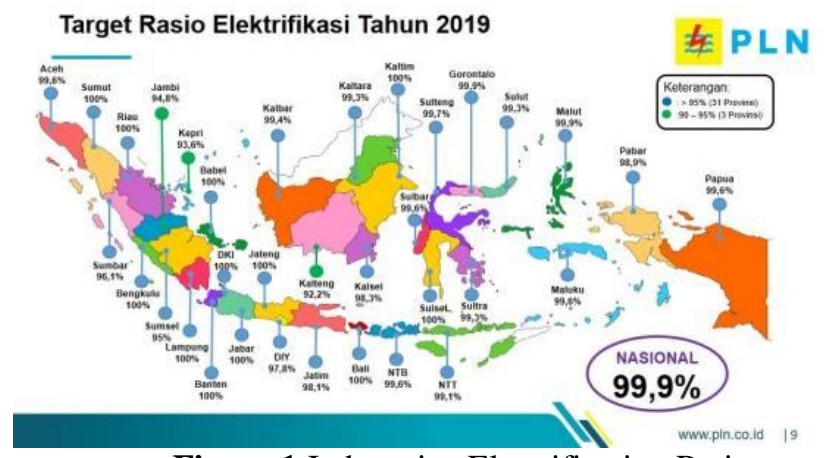

Figure 1:Indonesian Electrification Ratio

From the facts above it can be said that the challenges of electricity supply companies and supporting service providers such as O\&M generators will be very tight and competitive. That is because the opportunity to add new units is lower because the electricity reserves generated are almost $100 \%$. For this reason, O\&M service providers must develop strategies to increase competitive index in facing business competition. In supporting service providers such 
as O\&M business, the cost component is only from 2 components, namely component B (fixed cost) and component $\mathrm{D}$ (variable cost). In these two components, the biggest cost is in component $\mathrm{D}$, which is $80 \%$, in which there is a cost of providing spare parts, which is $62 \%$ of the total component cost B. For this reason, the optimal supply of spare parts plays an important role in maintaining the anticipated level of operational competitiveness, through efficient and effective engine maintenance [2].

Spare parts inventory management is very important for many companies, both in the manufacturing sector, namely automotive, food processing, the oil and gas industry, and so is the service sector, namely the telecommunications, electricity, water and other sectors [3] . The problem that arises in managing spare parts inventory is when providing sufficient and efficient supplies to support operational and maintenance activities in an industry [4]. A large number of organizations have problems relating to maintenance management due to the lack of adequate inventory management policies according to maintenance needs [5] Most of the spare parts are very expensive and have a high expenditure impact to be able to be used as a reserve stock, but on the other hand these parts are very much needed when considering flight cancellations, delays in logistics delivery or shutdown power plants [6]. In the planning of the operation and maintenance of electricity generation during tenders, there are many components of the tariff compiler that will be offered to the owner, the largest cost lies in the spare parts, ranging from $50-60 \%$ (figure 1) of the total O\&M costs. These costs are obtained from the total spare parts both scheduled (preventive maintenance) and unscheduled (emergency spare parts). Many companies still face high inventory problems that lead to substantial storage costs [7]. In general, the cost element of electricity generation consists of 5 components, component $\mathrm{A}$ or CAPEX, namely EPC costs and all investments, component $\mathrm{B}$ or fixed costs (spare parts, operator services, general, tools, etc.), component $\mathrm{C}$ or fuel costs, components $\mathrm{D}$ or variable cost (consumable) and component $\mathrm{E}$, which is transmission cost. Power plants with a long-term use will increase O\&M costs, where specifically one of the costs of concern is the cost of maintenance and repairs of the price of spare parts that must be in the warehouse

Spare parts inventory differs from inventory of manufactured products in many aspects [8]. Spare parts inventory is a field of research that is not as popular and not so much researched compared to production inventory [9]. Spare parts are very important sources to ensure availability [10]. Spare parts supply is related to demand from machines, while production inventory is related to demand from the production process [11]. Damage to a component of a piece of equipment, especially to electrical power generators, has a significant impact on the productivity of the equipment, which is caused by the availability of spare parts in the warehouse when unexpected disruptions occur. According to the manufacturer's recommendations, there is a minimum stock of emergency spare parts that must be in the warehouse apart from preventive parts so that the machine's availability performance is maintained. However, the recommendation is only based on the maintenance point of view and does not consider the amount of costs arising from the logistical side of the spare parts that must be present at the power plant site.

\section{Budgeting Component O\&M}

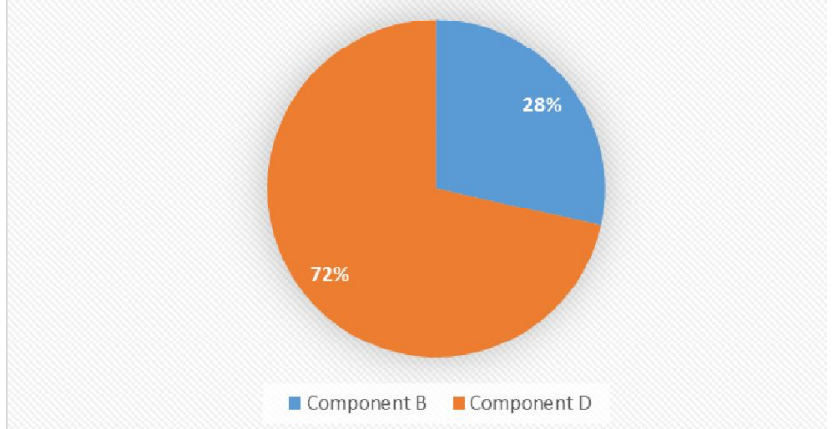

\section{Budgeting Component D}

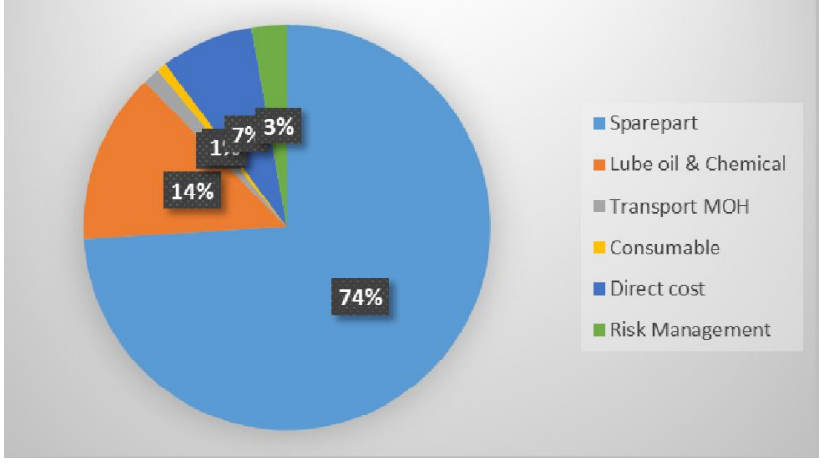

Figure2:Budgeting compotition O\&M Pembangkitlistrik

The criteria involved in classification must consider maintenance and logistical perspectives because both functions are involved in making decisions regarding spare parts stock levels [12]. Likewise, according to [13] that spare parts management mainly involves two fields, maintenance and logistics. The criteria involved in classification must consider maintenance and logistical perspectives because both functions are involved in making decisions regarding spare parts stock levels [14]. Maintenance and management of spare parts inventory are closely related and must be considered together [15]. For this reason, not only can the manufacturer's recommendations be used when preparing tenders as a reference, but they must also be maintained so that costs can be kept as low as possible so that O\&M cost offers to owners can be more competitive and can compete with other competitors, thereby increasing opportunities for employment the. The provision of optimal spare parts plays an important role in maintaining the level of anticipated operational competitiveness, through efficient and effective engine maintenance [16]. It is very important to find the right balance between the cost of spare parts, inventory, stock, and the cost of not using spare parts, while focusing on minimizing downtime costs [17]. Therefore, when 
Ennol Endrianto et al., International Journal of Emerging Trends in Engineering Research, 8(9), September 2020, 5477 - 5484

planning the number of emergency spare parts must be maintained so that the cost is low but does not interfere with the engine's performance from unpredictable interference and from the presence or absence of these spare parts when interruption. From several references, various criteria for deciding the minimum stock of emergency spare parts are described, so that they can be balanced in terms of maintenance and logistics, so the multi-criteria method is used with maintenance and logistics.Permintaanuntuk item sukucadangbiasanyaberselang,

denganpesanantibasecarasporadis,

danpermintaanjugabisasangatbervariasi[18].

permintaanhanyamunculpadagangguansistem.

Olehkarenaitu, permintaansukucadang yang intermiten, sporadis,

dansangatbervariasimengurangipenggunaanteknikperamalan dengankualitas yang sama[19].

From these various criteria, values will be calculated and the extent of the spare parts will be classified against the costs and maintenance interests. In some journals, to get priority is calculated using multy criteria decision making or using qualitative methods from expert opinion so that the interests of the spare parts are obtained. This method was chosen because it deals with decisions that involve the best alternative choices of several potential candidates in a decision, subject to several criteria or attributes that may be concrete or unclear [20].

The methods used are also very diverse, ranging from simple optimization calculations to non-linear, mixed-integer, and stochastic optimization models as practiced by [21]. Even so, the study of spare parts inventory has been so advanced that it has included various elements, including various cost elements, utility functions, probability of running out of inventory, and replenishment policies [22].

This thesis will discuss not only determining the priority criteria of the spare parts, with additional criteria assessed by the author more appropriate for use in power plants, but also calculating how many emergency spare parts should be provided during the tender process. Efficient and effective spare parts management is very important for maintenance management because it affects equipment downtime [23]. With the Multi Criteria method we will get the priority of spare parts which are viewed from the maintenance glasses as well as from the logistics glasses, after that the priority will be known which parts must exist in the warehouse, the recommended parts are there and the unnecessary parts are in the warehouse. After that there will be discussions with experts who previously used similar machines or types to determine the judgment quantity or amount that should be in the warehouse. From the type and value of the emergency spare part, it will be compared with the initial solution or recommendation from the manufacturer so that the subsequent tenders can be determined quickly the inventory costs [25-26].

\subsection{Inventory control in maintenance}

Usually, the major complaint of those involved in maintenance is the unavailability of materials and spare parts at the moment of need [10] Current conditions engineering equipment such as in power plants are growing with complexity and a high level of complexity where inventory costs can be very large and affect the cost and power performance itself during tenders and when they are operational.

In power plants, the availability of emergency spare parts is very influential on engine performance in the event of unexpected damage. When the unavailability of spare parts in the warehouse will result in the engine not being able to operate for a long time depending on the arrival of the parts needed by the mainatenance, this is worsened if the spare parts are not available domestically or must be imported as well as the availability at the manufacturer which must be pivot.

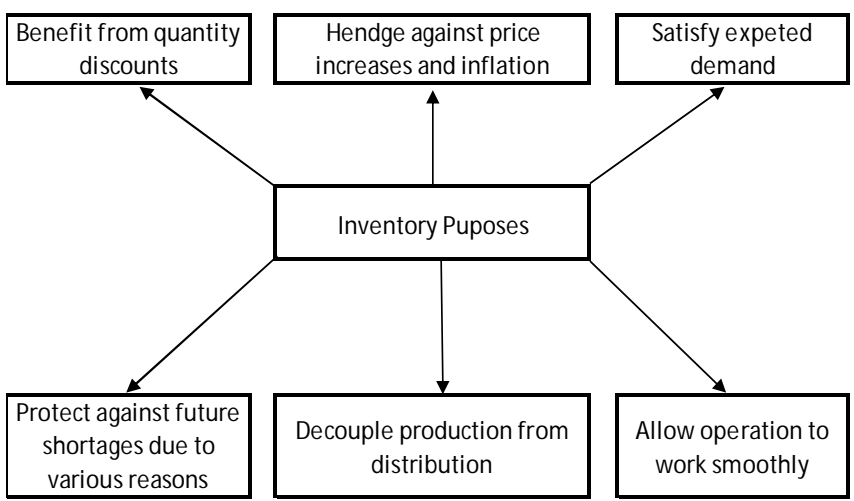

Figure 3:.Important purposes of inventory [10].

For this reason, maintenance management needs to make decisions on basic areas such as those listed below with respect to inventory [16].

- Items / materials to be stored: Decision requires consideration of factors such as the ability of the vendor to supply at the moment of need, cost and the degree of deterioration in storage.

- Amount of items / materials to be stored: decisions are made by considering factors such as us degree of usage and delivery lead time.

- Item / material suppliers: decisions on suppliers of items/materials are made by considering factors such as price, delivery, quality, and services.

- Lowest supply levels: decisions on the lowest level of suppliers, in particular the major store items, are made bu considering factors such as purchasing's historical records and projected needs

- Highest supply levels: as time-to-supply usage rate drops, the decision on the highest supply levels are made by keeping mind factors such as part ordering experiences and peak vacation periods

- Time to buy and pay: decisions on these two items are often interlocked 
- Place to keep items / materials: as location control is crucial to a productive maintenance department, decisions concerning storage of items / materials are made by keeping in mind that they can be effectively retrieved.
In any maintenance inventory control, parts for preventive activities must be available in the warehouse before the maintenance period. For breakdown maintenance or unscheduled activities, items must be controlled in such a way that capital investment inventory is most effective [24].

Table 2.Formatting sections, sub-sections and sub sub-sections

\begin{tabular}{|c|c|c|c|c|c|c|}
\hline Area & No & Kategori & Deskripsi & Kriteria & Keterangan & Point \\
\hline \multirow{19}{*}{ Maintenance } & \multirow[t]{3}{*}{1} & $\mathrm{C}_{\mathrm{s}}$ & \multirow[t]{3}{*}{ Ketegori spare part yang sering digunakan } & $\mathrm{V}$ & \multirow[t]{3}{*}{ spare part category } & 3 or 4 \\
\hline & & & & $\mathrm{E}$ & & 2 \\
\hline & & & & $\mathrm{D}$ & & 1 \\
\hline & \multirow[t]{3}{*}{2} & $\mathrm{C}_{\mathrm{t}}$ & \multirow[t]{3}{*}{ Waktu yang dibutuhkan untuk penggantian } & up to $2 \mathrm{hrs}$ & \multirow[t]{3}{*}{ Replacement time } & 1 \\
\hline & & & & $2-8 \mathrm{hrs}$ & & 2 \\
\hline & & & & over $8 \mathrm{hrs}$ & & 3 \\
\hline & \multirow[t]{3}{*}{3} & $C_{0} R$ & \multirow[t]{3}{*}{ Kerumitan untuk penggantian spare part } & Low - No special tools \& devices required & \multirow{3}{*}{ Complexity of replacement } & 1 \\
\hline & & & & Medium - Particular devices and tools are required & & 2 \\
\hline & & & & High - Special tools and tools are required & & 3 \\
\hline & \multirow[t]{2}{*}{4} & $\mathrm{~F}_{\mathrm{t}}$ & \multirow[t]{2}{*}{ Tipe kegagalan dan dampaknya pada engine } & Accidental & \multirow[t]{2}{*}{ Failure Type } & 1 \\
\hline & & & & Chronic & & 2 \\
\hline & \multirow[t]{3}{*}{5} & \multirow[t]{3}{*}{$F_{f}$} & \multirow{3}{*}{$\begin{array}{l}\text { Melihat histori dari mesin semirip sebagai } \\
\text { pembanding }\end{array}$} & up to 8 per year & \multirow[t]{3}{*}{ Demand pattern } & 1 \\
\hline & & & & 8-16 per year & & 2 \\
\hline & & & & over 16 per year & & 3 \\
\hline & \multirow[t]{3}{*}{6} & \multirow[t]{3}{*}{$E_{q}$} & \multirow[t]{3}{*}{ Skill pegawai } & Low - basic experience is required & \multirow[t]{3}{*}{ Qualification of employee } & 1 \\
\hline & & & & Medium - need special permission & & 2 \\
\hline & & & & Outsourcing & & 3 \\
\hline & \multirow{2}{*}{7} & \multirow{2}{*}{$O_{p}$} & \multirow{2}{*}{$\begin{array}{l}\text { pola operasi mesin yang bekerja secara terus } \\
\text { menerus atau peaker }\end{array}$} & Peaker & \multirow{2}{*}{ Operation Patern } & 2 \\
\hline & & & & Base load & & 3 \\
\hline Area & No & Kategori & Deskripsi & Kriteria & Keterangan & Point \\
\hline \multirow{18}{*}{ Logistic } & 1 & $C_{p}$ & Harga spare part & Low & Part cost & 1 \\
\hline & & & & Medium & & 2 \\
\hline & & & & High & & 3 \\
\hline & 2 & $\mathrm{~L}_{\mathrm{t}}$ & Waktu penyediaan & Short - up to $48 \mathrm{Hrs}$ & Lead Time & 1 \\
\hline & & & & Medium - from 48hrs-7days & & 2 \\
\hline & & & & Long - over 7 days & & 3 \\
\hline & 3 & $E_{p}$ & Populasi Engine di dalam negeri atau daerah & Banyak & Engine Popupation & 1 \\
\hline & & & & Sedikit & & 2 \\
\hline & & & & Tidak ada & & 3 \\
\hline & 4 & $\mathrm{P}_{\mathrm{f}}$ & Kemungkinan kegagalan spare part & high & Probality of failure & 3 \\
\hline & & & & medium & & 2 \\
\hline & & & & low & & 1 \\
\hline & 5 & $A_{e}$ & Ketersediaan & Tersedia & Availability of equipment & 1 \\
\hline & & & & Inden & & 2 \\
\hline & 6 & $I_{p}$ & Permasalahan persediaan & high & Inventory problem & 2 \\
\hline & & & & low & & 1 \\
\hline & 7 & $A_{t}$ & Ketersediaan gambar, mill of certificate & Yes & Availability of technical spesification & 1 \\
\hline & & & & No & & 2 \\
\hline
\end{tabular}

There are many ways to classify spare parts, according to [10] one of them is ABC classification, while the definitions are: item A classification is high priority item, item B classification is medium priority and item $\mathrm{C}$ classification or low priority. In the literature, it has been generally recognized that a "classical" $\mathrm{ABC}$ analysis may not be able to provide a good classification in practice (Altay Guvenir\&Erel, 1998). Another method is the division of spare parts into 3 other classifications, namely VED (Vital, Essential, desireable). The VED classification system is based on the maintenance expert's knowledge [23].

The main purpose of having the safety stock is to mitigate the risk of running out of items at the moment of need [10]. Therefore it must be determined carefully so that the business units that are being run are not interrupted by the availability of spare parts, or the costs are inflated due to too much stock warehouse. The two glasses are expected to balance and provide the best solution in terms of maintenance and logistics.

\subsection{Spare part criteria}

With so many considerations to safeguard the financial and performance of the power plant that will be operated, it is necessary to choose and prioritize what criteria should be considered for selecting and determining emergency spare parts for unscheduled maintenance activities.

As for the criteria that will be used in the case of the author, consisting of maintenance and logistics glasses, this will be explained in the table developed from the table [2] and also 
Ennol Endrianto et al., International Journal of Emerging Trends in Engineering Research, 8(9), September 2020, 5477 - 5484

[23] where the table is obtained from experts and consultants as well as the experience of these writers and we develop and adapt to the needs of our business units, namely businesses in the field of electricity generation

\subsection{Criteria Selection}

Maintenance and management of spare parts inventory are closely related and must be considered together [20]. For this reason, not only can the manufacturer's recommendations be used when preparing tenders as a reference, but they must also be maintained so that costs can be kept as low as possible so that O\&M cost offers to owners can be more competitive and can compete with other competitors, thereby increasing opportunities for employment the. The provision of optimal spare parts plays an important role in maintaining the level of anticipated operational competitiveness, through efficient and effective engine maintenance [2].

For this reason, in this study a logistic and maintenance approach was chosen to determine emergency spare parts, tables [2, 3, 22, 23] used as initial references added to conditions and novelty ideas to get results more ideal in accordance with the conditions of the power plant. Here are the research gaps

The addition of engine population on the inventory side is felt necessary because with the large number of engine populations in an area or country, the availability of spare parts in the market will be more numerous than the small population, thus also adding the operating conditions of the engine generator itself, where there is a base load condition work continuously or in peaker conditions or work only at certain hours in accordance with the peak load of electrical energy.

Emergency spare part evaluation here uses two points of view, namely in terms of $\mathrm{PCm}$ maintenance and also $\mathrm{PCl}$ logistics. Equation (1) and (2).

$$
\mathrm{PC}_{\mathrm{l}}=\mathrm{W}_{1} \mathrm{C}_{\mathrm{p}}+\mathrm{w}_{2} \mathrm{~L}_{\mathrm{t}}+\mathrm{W}_{3} \mathrm{E}_{\mathrm{p}}+\mathrm{w}_{4} \mathrm{P}_{\mathrm{f}}+\mathrm{w}_{5} \mathrm{~A}_{\mathrm{e}}+\mathrm{w}_{6} \mathrm{~L}_{\mathrm{p}}+\mathrm{w} 7 \mathrm{~A}_{\mathrm{t}}(2)
$$

The value and understanding of the formula above will be explained in the category table below with the value of $w$ adjusted to company policy.

\section{METHODOLOGY}

The research method used is to collect Primary data derived from bids, manual books, Tender documents using systematic research which is illustrated in the flow diagram of the research methodology in figure 3.1 The research methodology consists of 6 stages as follows:

\section{Introduction}

At this stage consists of determining the research topic, formulation of the problem, and research objectives based on literature study and discussion with the supervisor.

\section{Compilation of literature studies}

In this step, the theoretical basis is collected from various literatures related to the research topic, namely regarding electricity generation, cost and performance components, maintenance factors, logistics factors, Multi-criteria decision making, expert judgment

\section{Data Collection}

At this stage, data collection on Emergenc part components is offered from an international standard manufacturer. This offer data is a group of data that explains the type of part, pat number, price, and also lead time

\section{Data processing}

At this stage the process of evaluating each spare part is carried out using various proposed criteria, both in terms of maintenance and logistics, after knowing each of these values, the results will be obtained whether the part's interests should be there, recommended there are, and not need to be in the warehouse. From these data FGDs will be conducted to the experts to get judgment on the quantity of spare parts that must be provided. From these results will be compared with the recommendations of the manufacturer.

$$
\mathrm{PC}_{\mathrm{m}}=\mathrm{w}_{1} \mathrm{C}_{\mathrm{s}}+\mathrm{w}_{2} \mathrm{C}_{\mathrm{t}}+\mathrm{w}_{3} \mathrm{C}_{\mathrm{o}} \mathrm{R}+\mathrm{w}_{4} \mathrm{~F}_{\mathrm{t}}+\mathrm{w}_{5} \mathrm{~F}_{\mathrm{f}}+\mathrm{w}_{6} \mathrm{E}_{\mathrm{q}}+\mathrm{w}_{7} \mathrm{O}_{\mathrm{p}}(1)
$$

\begin{tabular}{|c|c|c|c|c|c|c|c|c|c|c|c|c|c|}
\hline Inventory site & & & & & & & & & & Maintenance site & & & \\
\hline Kriteria & $\begin{array}{c}\text { Botter \& } \\
\text { Fortuin } \\
(2000)\end{array}$ & \begin{tabular}{|l|} 
Braglia et \\
al (2004)
\end{tabular} & \begin{tabular}{|c|} 
Cakir \& \\
Canbolat \\
$(2008)$ \\
\end{tabular} & \begin{tabular}{|c|} 
Bosnjakovic \\
$(2010)$
\end{tabular} & \begin{tabular}{|c} 
Molenae \\
set al \\
$(2012)$
\end{tabular} & \begin{tabular}{|c|} 
Stoll et al \\
$(2015)$
\end{tabular} & \begin{tabular}{|c|} 
Antosz \\
\& Ratnaya \\
ka (2019) \\
\end{tabular} & \begin{tabular}{|c|} 
Figuerido \& \\
Catarina \\
Teixeira (2018)
\end{tabular} & Now & Kriteria & \begin{tabular}{|c|} 
Figuerido \& \\
Catarina Teixeira \\
$(2018)$ \\
\end{tabular} & $\begin{array}{c}\text { Antosz } \\
\& \text { Ratnayaka } \\
\text { (2019) }\end{array}$ & NOW \\
\hline Lead Time & $x$ & $x$ & $x$ & & $x$ & $x$ & $\frac{x}{x}$ & $x$ & $\bar{x}$ & Proces and control of critically & $\frac{x}{x}$ & & \\
\hline Price & $x$ & $x$ & $x$ & & & & $x$ & $x$ & $x$ & Specify & $x$ & & \\
\hline Probality of failure & & $x$ & & & $x$ & $x$ & & & $x$ & Demand patterns & $x$ & $x$ & $\mathrm{x}$ \\
\hline Number of potential suppliers & & & & $\mathrm{x}$ & $x$ & & $\mathrm{x}$ & & & Product value & $\mathrm{x}$ & & \\
\hline Annual demand & $\mathrm{x}$ & $\mathrm{x}$ & $x$ & & & & & & & Machine category & & $\mathrm{x}$ & $\mathrm{x}$ \\
\hline Availability of equipment & & & & & $\mathrm{x}$ & $\mathrm{x}$ & & & $\mathrm{x}$ & Time & & $x$ & $\mathrm{x}$ \\
\hline Inventory problem & & $x$ & & $\mathrm{x}$ & & & & & $x$ & Complecity & & $x$ & $\mathrm{x}$ \\
\hline Availability of technical spesification & & & & & $\mathrm{x}$ & $\mathrm{x}$ & & & $x$ & type of failure & & $\mathrm{x}$ & $\mathrm{x}$ \\
\hline Installation time & & & & & & $x$ & & & & Employee qualifications & & $x$ & $\mathrm{x}$ \\
\hline Storage & & & & & & & $x$ & & & Operation patern (peaker/baseload) & & & $x$ \\
\hline Engine Population & & & & & & & & & $x$ & & & & \\
\hline
\end{tabular}

Table 2.Research Gap. 


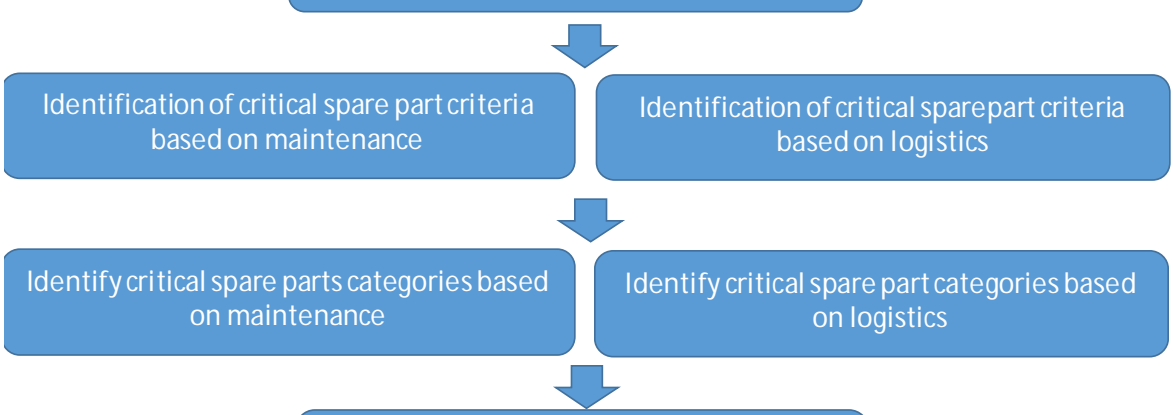

Determine the critical level between the

maintenance and logistics angle

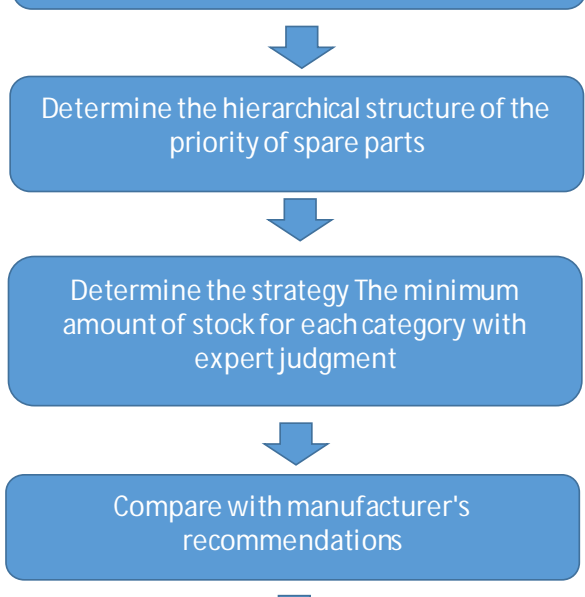

\section{Result}

\section{RESULT AND DISCUSSION}

\subsection{Case Study}

In this section, an application example of the classification methodology criteria is presented. We take the parts from 5 powerplants with total sapare parts is amount 597 for emergency spare parts. The firs step is critically determines spare parts that must be stored in the warehouse for keeping the powerplants in good performances, after calculating the critical level of spare parts and found what type of spare parts must be in stock, then the second step is to ask the opinions of experts on these conditions to determine the amount. at this stage the expert in question has at least 5 years experience in the world of O\&M powerplant especially powerplant that is as similar as the type of gas engine powerplant. experts used for this stage are around 12 people and will be added during the discussion of the original book.

\subsection{Multi-criteria classification}

First, we will calculate the $\mathrm{Cm}$ spare part criteria by using the table of combination matrix [23] for determining the part using production impact vs. the function of the spare parts. The spare parts will be classified in Vital, Essential, Desireable from the multiplication number.

\subsection{Quantity Judgement}

Expert judgment is used after knowing critical spare parts where the critical $\mathrm{H}$ value then the spare parts must be in accordance with the manufacturer's request so that expert opinion will not be sought so that the quantity is fixed and does not change.

As for critical M spare parts, it will be thrown to the expert to be asked for opinions about the value that should be maintained at the warehouse to maintain the performance of the power plant when operating.

\begin{tabular}{|c|c|c|c|c|c|c|}
\hline & \multicolumn{4}{|c|}{ Production Impact } & \\
\hline & & 0 & 1 & 2 & 3 & \\
\hline \multirow{3}{*}{ 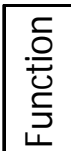 } & 1 & 1 & 2 & 3 & - & Desireable \\
\hline & 2 & 2 & - & 4 & 5 & Essential \\
\hline & 3 & - & 4 & 5 & 6 & Vital \\
\hline
\end{tabular}

Figure 4: Combination matrix(Teixeira, Figueiredo, Lopes, 2018) 
Ennol Endrianto et al., International Journal of Emerging Trends in Engineering Research, 8(9), September 2020, 5477 - 5484

Table 3:VED Spare part category.

\begin{tabular}{|c|c|c|c|c|c|c|c|c|c|c|c|}
\hline No & Name & Part number & system & OEM & Origin & Project & function & product impact & sum & Classification & Spare part category \\
\hline 1 & Seal-crankcase cover FE-side & DOT.073.24.056 & Crankcase co vering on injection side & MAN & Jerman & Seram & 1 & 0 & & Desireable & 1 \\
\hline 2 & Seal-crankcase cover FE-side & DOT.073.24.057 & Crankcase covering on injection side & MAN & Jerman & Seram & 1 & 0 & & Desireable & 1 \\
\hline 3 & Seal ring - crankcase cover & DOT.073.24.A05 & Crankcase covering on injection side & MAN & Jerman & Seram & 1 & 0 & & Desireable & 1 \\
\hline 4 & Seal - relief valve & DOT.073.24.B03 & Crankcase covering on injection side & MAN & Jerman & Seram & 1 & 0 & & Desireable & 1 \\
\hline 5 & Seal ring-camshaft cover & DOT.077.03.060 & Camshaft covering & MAN & Jerman & Seram & 2 & 1 & & Essential & 2 \\
\hline 6 & Upper bearing shell & DOT.021.08.001 & Crankshaft bearing & MAN & Jerman & Seram & 3 & 2 & & Vital & 3 \\
\hline 7 & Lower bearing shell & DOT.021.08.002 & Crankshaft bearing & MAN & Jerman & Seram & 3 & 2 & & Vital & 3 \\
\hline 8 & Location bearing ring & DOT.021.08.003 & Crankshaft bearing & MAN & Jerman & Seram & 3 & 2 & & Vital & 3 \\
\hline 9 & Non return valve & DOT.030.07.008 & Connecting rod & MAN & Jerman & Seram & 1 & 1 & & Desireable & 1 \\
\hline 10 & Upper bearing shell & DOT.030.07.024 & Connecting rod & MAN & Jerman & Seram & 1 & 1 & & Desireable & 1 \\
\hline 11 & Lower bearing shell & DOT.030.07.025 & Connecting rod & MAN & Jerman & Seram & 1 & 1 & & Desireable & 1 \\
\hline 12 & Compression ring & DOT.034.16.001 & Piston/piston rings/piston pin & MAN & Jerman & Seram & 3 & 3 & & Vital & 4 \\
\hline 13 & Compression ring & DOT.034.16.002 & Piston/piston rings/piston pin & MAN & Jerman & Seram & 3 & 3 & & Vital & 4 \\
\hline 14 & Oil control ring & DOT.034.16.003 & Piston/piston rings/piston pin & MAN & Jerman & Seram & 3 & 3 & & Vital & 4 \\
\hline 15 & Piston pin & DOT.034.22.010 & Piston/piston rings/piston pin & MAN & Jerman & Seram & 3 & 3 & & Vital & 4 \\
\hline
\end{tabular}

Table 4. Assesment the spare parts.

\begin{tabular}{|c|c|c|c|c|c|c|c|c|c|c|c|c|c|c|c|c|c|c|c|c|c|c|c|}
\hline No & Name & Part number & Qty & $C_{s}$ & $c_{1}$ & $C_{0} R$ & $\mathrm{~F}_{\mathrm{t}}$ & $F_{f}$ & $E_{q}$ & $O_{p}$ & $\mathrm{P}_{f}$ & $A_{e}$ & $I_{p}$ & $A_{t}$ & $c_{p}$ & 4 & $E_{p}$ & Maintenance & Logistic & Maintenance & Logistic & Spareparts category & Sparepart critically \\
\hline 1 & Seal-crankcase cover FE-side & DOT.073.24.056 & & 1 & 1 & 1 & 1 & 1 & 3 & 2 & 2 & 1 & 1 & 1 & 2 & 3 & 2 & 1.35 & 1.90 & $\mathrm{C}$ & $\mathrm{B}$ & CB & M \\
\hline 2 & Seal-crankcase cover FE-side & DOT.073.24.057 & & 1 & 1 & 1 & 1 & 1 & 3 & 2 & 2 & 1 & 1 & 1 & 2 & 3 & 2 & 1.35 & 1.90 & c & B & $C B$ & M \\
\hline 3 & Seal ring - crankcase cover & DOT.073.24.A05 & & 1 & 1 & 1 & 1 & 1 & 3 & 2 & 2 & 1 & 1 & 1 & 2 & 3 & 2 & 1.35 & 1.90 & c & B & $C B$ & M \\
\hline 4 & Seal - relief valve & DOT. $073.24 . \mathrm{B} 03$ & & 1 & 1 & 1 & 1 & 1 & 3 & 2 & 2 & 1 & 1 & 1 & 2 & 3 & 2 & 1.35 & 1.90 & c & $B$ & $C B$ & M \\
\hline 5 & Seal ring - camshaft cover & DOT.077.03.060 & & 2 & 2 & 2 & 1 & 1 & 1 & 2 & 2 & 1 & 1 & 1 & 2 & 3 & 2 & 1.65 & 1.90 & B & B & BB & M \\
\hline 6 & Upper bearing shell & DOT.021.08.001 & & 3 & 3 & 3 & 2 & 1 & 1 & 2 & 3 & 1 & 1 & 1 & 3 & 3 & 2 & 2.30 & 2.30 & B & B & BB & M \\
\hline 7 & Lower bearing shell & DOT.021.08.002 & & 3 & 3 & 3 & 2 & 1 & 1 & 2 & 3 & 1 & 1 & 1 & 3 & 3 & 2 & 2.30 & 2.30 & B & B & BB & M \\
\hline 8 & Location bearing ring & DOT.021.08.003 & & 3 & 3 & 3 & 2 & 1 & 1 & 2 & 3 & 1 & 1 & 1 & 3 & 3 & 2 & 2.30 & 2.30 & B & B & BB & M \\
\hline 9 & Non return valve & DOT.030.07.008 & & 1 & 2 & 3 & 1 & 1 & 2 & 2 & 2 & 1 & 1 & 1 & 2 & 3 & 2 & 1.55 & 1.90 & B & B & BB & M \\
\hline 10 & Upper bearing shell & DOT.030.07.024 & & 1 & 2 & 3 & 1 & 1 & 2 & 2 & 2 & 1 & 1 & 1 & 2 & 3 & 2 & 1.55 & 1.90 & B & B & BB & M \\
\hline 11 & Lower bearing shell & DOT.030.07.025 & & 1 & 2 & 3 & 1 & 1 & 2 & 2 & 2 & 1 & 1 & 1 & 2 & 3 & 2 & 1.55 & 1.90 & B & B & BB & M \\
\hline 12 & Compression ring & DOT.034.16.001 & & 4 & 2 & 3 & 2 & 1 & 3 & 3 & 4 & 1 & 1 & 1 & 3 & 3 & 2 & 2.85 & 2.40 & A & B & $A B$ & $\mathrm{H}$ \\
\hline 13 & Compression ring & DOT. 034.16 .002 & & 4 & 2 & 3 & 2 & 1 & 2 & 2 & 4 & 1 & 1 & 1 & 3 & 3 & 2 & 2.60 & 2.40 & $\hat{A}$ & B & $A B$ & $\mathrm{H}$ \\
\hline 14 & Oil control ring & DOT.034.16.003 & & 4 & 2 & 3 & 2 & 1 & 2 & 2 & 4 & 1 & 1 & 1 & 3 & 3 & 2 & 2.60 & 2.40 & A & B & $A B$ & $\mathrm{H}$ \\
\hline 15 & Piston pin & DOT 034,22010 & & 4 & 2 & 1 & 2 & 1 & 2 & 2 & 4 & 1 & 1 & 1 & 3 & 3 & 2 & 240 & 240 & B & B & BB & $M$ \\
\hline
\end{tabular}

Table 5. Spare part critically " $\mathrm{H}$ ".

\begin{tabular}{|c|c|c|c|c|c|c|c|c|c|c|c|c|c|c|c|c|c|c|c|c|c|c|}
\hline No - & Name & Part number- & Qty & $c_{-1}$ & $c_{-1}$ & $C_{0}{ }_{2}$ & $\mathrm{~F}_{-}$ & $\mathrm{F}_{\mathbf{2}}$ & $E_{\nu}$ & 0. & P. & $A_{-}$ & $I_{R=1}$ & $A_{-1}$ & $c_{-1}$ & $L_{-1}$ & $E_{-}$Maintenan $=$ & Logisiva & Maintenan $=$ & Logistic & 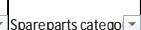 & Sparepart critically $\pi$ \\
\hline 12 & Compression ring & DOT.034.16.001 & 3 & 4 & 2 & 3 & 2 & 1 & 3 & 3 & 4 & 1 & 1 & 1 & 3 & 3 & 2.85 & 2.40 & $\mathrm{~A}$ & B & $A B$ & $\mathrm{H}$ \\
\hline 13 & Compression ring & DOT.034.16.002 & 3 & 4 & 2 & 3 & 2 & 1 & 2 & 2 & 4 & 1 & 1 & 1 & 3 & 3 & 2.60 & 2.40 & A & B & $A B$ & $\mathrm{H}$ \\
\hline 14 & Oil control ring & DOT.034.16.003 & 3 & 4 & 2 & 3 & 2 & 1 & 2 & 2 & 4 & 1 & 1 & 1 & 3 & 3 & 2.60 & 2.40 & A & B & $A B$ & $\mathrm{H}$ \\
\hline 26 & Cylinder head compl - with all valves & DOT.055.07.CPL & 1 & 4 & 3 & 2 & 2 & 1 & 2 & 2 & 4 & 1 & 1 & 1 & 3 & 3 & 2.60 & 2.40 & A & B & $A B$ & $\mathrm{H}$ \\
\hline 68 & Compression spring & DOT.200.02.020 & 1 & 4 & 1 & 3 & 2 & 1 & 2 & 2 & 4 & 1 & 1 & 1 & 3 & 3 & 2.50 & 2.40 & A & B & $A B$ & $\mathrm{H}$ \\
\hline 73 & Fuel injection pump, complete & DOT.200.08.K & 1 & 4 & 3 & 3 & 2 & 1 & 2 & 2 & 4 & 1 & 1 & 1 & 3 & 3 & 2.70 & 2.40 & A & B & $A B$ & $\mathrm{H}$ \\
\hline 74 & Fuel pump assembly - ind. valve support & DOT 200. SPK.003 & 1 & 4 & 1 & 3 & 2 & 1 & 2 & 2 & 4 & 1 & 1 & 1 & 3 & 3 & 2.50 & 2.40 & A & $B$ & $A B$ & $\mathrm{H}$ \\
\hline
\end{tabular}

Table 6. Expert Judgement

\begin{tabular}{|c|c|c|c|c|c|c|c|c|c|c|c|c|c|c|c|c|c|c|c|c|c|c|c|c|}
\hline No & Name & Part number & Qty & Expert Judgement & $c_{5}$ & $c_{t}$ & $C_{0} R$ & $\mathrm{~F}_{\mathrm{t}}$ & $F_{f}$ & $E_{q}$ & $O_{p}$ & $P_{t}$ & $A_{e}$ & $I_{p}$ & $A_{t}$ & $c_{p}$ & 4 & $E_{p}$ & Maintenance & Logistic & Maintenance & Logistic & Spareparts category & Sparepart critically \\
\hline & & & & & 0.3 & 0.1 & 0.1 & 0.15 & 0.1 & 0.1 & 0.15 & 0.1 & 0.1 & 0.1 & 0.1 & 0.3 & 0.2 & 0.1 & & & & & & \\
\hline 1 & Seal-crankcase cover FE-side & DOT.073.24.056 & & 1 & 11 & 1 & 1 & 1 & 1 & 3 & 2 & 2 & 1 & 1 & 1 & 2 & 3 & 2 & 1.35 & 1.90 & c & B & CB & M \\
\hline 2 & Seal-crankcase cover FE-side & DOT.073.24.057 & & 1 & 11 & 1 & 1 & 1 & 1 & 3 & 2 & 2 & 1 & 1 & 1 & 2 & 3 & 2 & 1.35 & 1.90 & c & B & CB & M \\
\hline 3 & Seal ring - crankcase cover & DOT.073.24.A05 & & 1 & 11 & 1 & 1 & 1 & 1 & 3 & 2 & 2 & 1 & 1 & 1 & 2 & 3 & 2 & 1.35 & 1.90 & C & B & $C B$ & M \\
\hline 4 & Seal - relief valve & DOT.073.24.B03 & & 1 & 1 & 1 & 1 & 1 & 1 & 3 & 2 & 2 & 1 & 1 & 1 & 2 & 3 & 2 & 1.35 & 1.90 & c & B & $C B$ & M \\
\hline 5 & Seal ring-camshaft cover & DOT.077.03.060 & & 1 & 12 & 2 & 2 & 1 & 1 & 1 & 2 & 2 & 1 & 1 & 1 & 2 & 3 & 2 & 1.65 & 1.90 & B & B & BB & M \\
\hline 6 & Upper bearing shell & DOT.021.08.001 & & 1 & 13 & 3 & 3 & 2 & 1 & 1 & 2 & 3 & 1 & 1 & 1 & 3 & 3 & 2 & 2.30 & 2.30 & B & B & $\mathrm{BB}$ & M \\
\hline 7 & Lower bearing shell & DOT.021.08.002 & & & 13 & 3 & 3 & 2 & 1 & 1 & 2 & 3 & 1 & 1 & 1 & 3 & 3 & 2 & 2.30 & 2.30 & B & B & BB & M \\
\hline 8 & Location bearing ring & DOT.021.08.003 & & & 3 & 3 & 3 & 2 & 1 & 1 & 2 & 3 & 1 & 1 & 1 & 3 & 3 & 2 & 2.30 & 2.30 & B & B & BB & M \\
\hline 9 & Non return valve & DOT.030.07.008 & & 1 & 1 & 2 & 3 & 1 & 1 & 2 & 2 & 2 & 1 & 1 & 1 & 2 & 3 & 2 & 1.55 & 1.90 & B & B & BB & M \\
\hline 10 & Upper bearing shell & DOT.030.07.024 & & 1 & 1 & 2 & 3 & 1 & 1 & 2 & 2 & 2 & 1 & 1 & 1 & 2 & 3 & 2 & 1.55 & 1.90 & B & B & BB & M \\
\hline 11 & Lower bearing shell & DOT.030.07.025 & & & 1 & 2 & 3 & 1 & 1 & 2 & 2 & 2 & 1 & 1 & 1 & 2 & 3 & 2 & 1.55 & 1.90 & B & B & $\mathrm{BB}$ & M \\
\hline 12 & Compression ring & DOT.034.16.001 & & & 4 & 2 & 3 & 2 & 1 & 3 & 3 & 4 & 1 & 1 & 1 & 3 & 3 & 2 & 2.85 & 2.40 & A & B & $A B$ & $\mathrm{H}$ \\
\hline 13 & Compression ring & DOT.034.16.002 & & & 4 & 2 & 3 & 2 & 1 & 2 & 2 & 4 & 1 & 1 & 1 & 3 & 3 & 2 & 2.60 & 2.40 & A & B & $A B$ & H \\
\hline 14 & Oil control ring & DOT.034.16.003 & & & 4 & 2 & 3 & 2 & 1 & 2 & 2 & 4 & 1 & 1 & 1 & 3 & 3 & 2 & 2.60 & 2.40 & A & B & $A B$ & H \\
\hline 15 & Piston pin & DOT.034.22.010 & & & 14 & 2 & 1 & 2 & 1 & 2 & 2 & 4 & 1 & 1 & 1 & 3 & 3 & 2 & 2.40 & 2.40 & B & B & BB & M \\
\hline
\end{tabular}

\section{CONCLUSION}

In this paper it was found that the number of parts that must be provided in accordance with the manufacturer's request is $6 \%$ of the total spare parts of the five power plant locations with the type of gas engine powerplant. The value of spare parts that can be adjusted to the conditions of the generator in this case in accordance with the opinion of the experts is $94 \%$ of the total spare parts, while the number of spare parts that are neglected to not be provided is $0 \%$.

The decrease in the number of spare parts that must be stocked as a whole fell to only $71 \%$ and for costs also decreased in the initial planning offered by the manufacturer to $72 \%$.In total, the use of the above method can reduce inventory costs by $28 \%$ from the initial planning of the tender where the amount can be used as a bargaining reserve value in the overall O\&M price to the owner.

\section{ACKNOWLEDGEMENT}

Alhamdulillahirabil 'alamin, the researcher expressed his highest gratitude to Allah Subhanahuwata'ala for blessings, love, opportunity, health, and grace to complete this undergraduate thesis. This thesis is entitled "Determination of emergency spare parts using the logistics and maintenance perspective on power plants" Submitted as a final requirement in completing a bachelor's degree at the University of Indonesia. Department of Industry

\section{REFERENCES}

1. Alijunir, Fachransyah., \&Zagloel, T.Y.M. (2019). Model Integrasipersediaansukucadang dan preventive maintenance denganmemperhitungkanfaktorwaktucooling down dan dismantlingmesin. PascasarjanaTeknikIndustriSalemba.
Program 
Ennol Endrianto et al., International Journal of Emerging Trends in Engineering Research, 8(9), September 2020, 5477 - 5484

2. Antosz, K., \&Ratnayake, R.M.C. (2019). Spare parts' criticallyassessment and prioritization for enhancingmanufacturing system' availability and realibility. Journal of manufacturing system 50 (2019) 212-225

3. Bošnjaković, M (2010). Multicriteriainventory model for spare part. Technical Gazette, 17,499-504

4. Botter, R.,\&Fortuin,L (2000). Stockingstrategy for service parts - a case study. International Journal of Operation and Production Management, 20(6), 656-674

5. Braglia,M., Grassi,A.,\&Montanary,R. (2004). Multiatribut classification method for spare part inventory management. Journal of Quality in Maintenance Engineering, 10(1),55-65.

6. Cakir,O., \&Canbolat,M.S. (2008). A webbaseddecisison support system for multicriteriainventory classification usingfuzzy AHP. Expert System with Applications, 35(3), 1367-1278.

7. Cavalieri, S., Garreti, M., Machhi, M., \& Pinto, R (2008). A decision-makingframework for managing maintenance spare parts. Production Planning \& Control, 19(4),379-396.

8. Cheng, G.Q.,Zhou,B.H., \& Li. (2018). Integrated production, quality control and condition-based maintenance for imperfect production systems. Reliability Engineering \& System Safety, 175 (September 2017), 251-264.

9. C.L.P. Pennings, J. van Dalen, E.A. van der Laan (2017). Exploitingelapsed time for managing intermittent demand for spare parts. Eur J OperRes, 258 (3) (2017), pp. 958-969

10. Dhillon.B.S (2002). Engineering maintenance a modern approach. Chaper 7

11. https://www.kompasiana.com/gatot_tri/5d412ad6097f3 635fa7d7b62/kabar-progres-program-listrik-35-000mw-menuju-rasio-elektrifikasi-100-persen?page=all. Dikunjungipada 10 Oktober 2019

12. https://www.esdm.go.id/id/media-center/arsipberita/rasio-elektrifikasi-999-tahun-2019-jonanseluruh-anak-bangsa-harus-rasakan-penerangan. Dikunjungipada 10 Oktober 2019

13. J.E. Boylan, A.A. Syntetos (2008). Forecasting for inventory management of service parts, K.A.H. Kobbacy, D.N.P. Murthy (Eds.), Complex system maintenance handbook., Springer Verlag, New York pp. 479-506

14. Kennedy, W.J., Wayne Patterson, J.,\&Fredendall,L.D (2002). An Overview of recentliterature on sparep part inventories. International Journal of Production economics, 76(2), 201-215.

15. Malik, M, F., \& Nurcahyo, R. (2017). Pengelolaanpengadaansukucadangpesawatterbangdeng anklasifikasi multi kriteria. Program PascasarjanaTeknikIndustriSalemba.

16. Meister,D., (1966) .Humanfactorsinnreliability, in reliabilityhandbook. Newyork, 12.2-12.37

17. Molenaers,A., Baets,H., Pintelon,L., \& Waeyenbergh,G. (2012). Critically classification of spare parts : a case study. International Journal of production Economics, 140(2), 570-578.
18. Niebel, B.W (1994). Engineering maintenance management.

19. Pavan.R.Todeschini (2009). ComprehensiveChemometricsChemical and Biochemical Data Analysis, Volume 1, , Pages 591-629

20. Prihandoyo,A.A., Zagloel, T.Y., \&Ardi, R (2018). Integrationcost model of predictive maintenance and stock inventorywithconsideration of multiechelonlogostic. Asia Pacific Confrence on Reasearch in Industria and System Engineering, 65-69.

21. Roda, I., Macchi, M.,Fumagalli, L.,\&Viveros,P (2014). A review of multi-criteria classification of spare part : Fromliteratureanalysis to industrialecidences. Journal of ManufacturingTechnology management, 25(4), 528549.

22. Stoll,J., Kopf, R., Schneider,J., \&Lanza,G. (2015). Criticallyanalysis of spare part management : A multicriteria classification regardinga cross-plant central warehousestrategy. Production Engineering, 9(2),225235.

23. Teixeira, C., Figueiredo, M., \& Lopes, I. (2018). Classification methodology for spare parts management combiningmaintenance and logistics perspectives. Journal of Management Analytics,ISSN : 2327-0012.

24. Wang, W.A (2012). A stochastic model for joint spare parts inventory and planned maintenance optimization.Eur J OperRes 2012;216(1):127-39.

25. B. William, K. Malubaya, and G. Wang, "Real-time Parking Information System with Cloud Computing Open Architecture Approach," Int. J. Emerg. Trends Eng. Res., vol. 8, no. 1, pp. 18-22, 2020.

26. J. K. R. Sastry, M. T. Basu, K. Lakshmaiah, and E. Foundation, "Multi-Factor Authentication through Integration with IMS System," Int. J. Emerg. Trends Eng. Res., vol. 8, no. January, pp. 87-113, 2020. 